\title{
Optimalisasi Produktivitas Lahan Sempit di Desa Sigerongan Lingsar Lombok Barat melalui Penerapan Tumpangsari Sayuran Okra dan Beberapa Genotipe Kacang Tanah
}

\author{
A. Farid Hemon*, Sumarjan, Baiq Erna Listiana \\ Program Studi Agroekoteknologi Fakultas Pertanian Universitas Mataram, Mataram, NTB, Indonesia
}

\author{
Article history \\ Received: 15 Maret 2020 \\ Revised: 25 Maret 2020 \\ Accepted: 11 Mei 2020 \\ *Corresponding Author: \\ A. Farid Hemon \\ Program Studi \\ Agroekoteknologi \\ Fakultas Pertanian \\ Universitas Mataram, \\ Mataram, NTB, \\ Indonesai; \\ Email: \\ faridhemon_1963@yahoo.com.
}

\begin{abstract}
This extension activity aimed to help Farmer Group partner of the "Sumber Hidup" in Sigerongan Village to increased the productivity of narrow land through the application of intercropping technology between okra crop and peanut genotypes. The program that implemented were the application of science and technology with stages of activities, namely: 1) dissemination activities "optimization of productivity of narrow land through the application of intercropping okra and peanuts and the application of technology to increased production of okra and peanut". This activity was carried out with a lecture and discussion system between the Extension Team and the Farmer Group, and 2) plot demonstration program. Farmers directly participated in planing, planting, crop maintaining, comparing and evaluating whether the implemented program will benefit or not. The results of the activity showed that the farmers participating in the extension were very responsive to the dissemination of intercropping okra-peanut. This was reflected in the participants' enthusiasm in asking questions and having discussions between participants with Team. In addition, participants were also active in participating in each stage of activities such as selecting seed quality, making demonstration plots, planting, growing, weeding, controlling pests and diseases, and harvesting activities. The transformation process of the okra-peanut intercropping technology in the narrow land of Sigerongan Village has implemented, with the hope that farmers will be able to take advantage the narrow land by planting intercropping. Cultivation of okra-peanut intercropping was more productive with an LER value of 2.28 compared to peanut monoculture and 1.35 compared to okra monoculture.
\end{abstract}

Keywords: intercropping; land equivalent ratio (LER); dissemination; plot demonstration

Abtrak: Kegiatan penyuluhan ini bertujuan untuk membantu mitra "Kelompok Tani Sumber Hidup" yang ada di Desa Sigerongan untuk meningkatan produktivitas lahan sempit melalui penerapan teknologi tumpangsari antara tanaman okra dengan beberapa genotipe kacang tanah. Program yang dilaksanakan merupakan penerapan ilmu dan teknologi dengan tahapan kegiatan, yaitu: 1) kegiatan diseminasi "optimalisasi produktivitas lahan sempit melalui penerapan tumpangsari sayuran okra dan kacang tanah dan penerapan teknologi peningkatan produksi sayuran okra dan kacang tanah". Kegiatan ini dilaksanakan dengan sistem ceramah dan diskusi antara Tim Penyuluh dengan Kelompok Tani, dan 2) program demonstrasi plot dengan melibatkan petani. Petani secara langsung ikut meencanakan, menanam, memelihara, membandingkan, dan mengevaluasi apakah program yang dilaksanakan akan memberi keuntungan atau tidak. Hasil kegiatan menunjukkan bahwa petani peserta penyuluhan sangat respons terhadap kegiatan diseminasi tumpangsari okra-kacang tanah. Hal ini 
tercermin dari antosias peserta dalam mengajukan pertanyaan dan adanya diskusi antara peserta dengan penyuluh. Selain itu peserta juga aktif dalam keikutsertaan dalam setiap tahapan kegiatan seperti pemilihan benih yang baik, pembuatan demplot, penanaman, pembumbunan, penyiangan, pengendalian hama dan penyakit, dan kegiatan panen. Proses transformasi teknologi tumpangsari okra-kacang tanah di lahan sempit Desa Sigerongan telah terjadi, dengan harapan petani mampu memanfaatkan lahan sempit dengan menanam secara tumpangsari. Penanaman tumpangsari okrakacang tanah lebih produktif dengan nilai LER 2,28 dibanding monokultur kacang tanah dan 1,35 dibanding monokultur okra.

Kata kunci: tumpangsari; Land Equivalent Ratio (LER); diseminasi; demplot

\section{PENDAHULUAN}

Kecamatan Lingsar Kabupaten Lombok Barat adalah salah satu daerah pengembangan kacang tanah dan sayuran di pulau Lombok. Kecamatan Lingsar mempunyai luas wilayah $74,5 \mathrm{~km}^{2}$ dan merupakan salah satu areal pertanian yang mendapat irigasi teknis, bentuk lahan datar dan berbukit. Mata pencaharian penduduk sebagian besar (85\%) adalah bertani dan sebagian besar dilakukan pada luas lahan sempit (10-20 are) dan sebagian besar petani adalah petani penggarap dan buruh tani dengan tingkat pendapatan petani yang rendah.

Salah satu alternatif pengembangan usaha tani di lahan sempit adalah dengan teknologi tumpangsari. Tumpangsari merupakan suatu usaha menanam beberapa jenis tanaman pada lahan dan waktu yang sama, yang diatur sedemikian rupa dalam barisan-barisan tanaman. Penanaman dengan cara ini bisa dilakukan pada dua atau lebih jenis tanaman yang relatif seumur, misalnya jagung dan kacang tanah atau bisa juga pada beberapa jenis tanaman yang umurnya berbeda-beda (Asadi et al., 1997).

Teknologi tumpangsari tanaman sayuran okra (Abelmoschus esculentus) dengan kacang tanah sangat jarang dilakukan, terutama karena sayuran okra tidak dipahami manfaatnya untuk kesehatan. Tanaman okra merupakan tanaman yang belum secara luas dikenal di Indonesia dan okra merupakan salah satu tanaman introduksi dan dibudidayakan dalam skala kecil oleh petani dan penyebutan tanaman ini berbeda-beda antar suku di NTB, suku Mbojo menyebutnya Bamea, Samawa menyebut Jemea sedangkan masyarakat Sasak menyebutnya kacang bendi. Tanaman okra kaya akan vitamin, mineral dan serat (Oyelade et al., 2003). Okra merupakan tanaman multiguna karena berbagai kasiat dari daun segar, tunas, bunga, polong, dan biji (Mihretu et al., 2014). Tanaman Okra dalam $100 \mathrm{~g}$ mengandung sebanyak 33 kalori, lemak total 0,2 g, karbohidrat 7,5 $\mathrm{g}$, serat $3,2 \mathrm{~g}$ atau $12,8 \%$, protein $1,9 \mathrm{~g}$, gula $1,5 \mathrm{~g}$, berbagai mineral kalsium, magnesium, potassium, dan berbagai vitamin C, timin, B6, folat, vitamin, dan vitamin K (Franklin, et al., 2015). Menurut Iwan (1995), di Jepang okra dijadikan makanan pelengkap dengan sebutan okura, sedangkan di India, okra dimasak menjadi makanan kebangsaan yang disebut dengan kari. Hasil survei awal di Hero Supermarket menunjukkan bahwa sayuran okra sangat potensi secara ekonomi dengan harga jual $100 \mathrm{~g}$ (4-5 buah segar) Rp. 5.000,-

Melihat manfaat nutrizi dan nilai ekonomis tanaman okra tersebut, maka kegiatan diseminasi dan adopsi tanaman okra pada petani di desa Sigerongan menjadi sangat penting untuk dilakukan. Petani di desa Sigerongan biasa melakukan usaha tani kacang tanah secara monokultur. Hasil pengamatan awal di lokasi menunjukkan bahwa rata-rata produksi kacang tanah adalah sekitar $\pm 1,1$ ton polong kering dan masih sangat rendah dari produksi nasional 3-4 ton polong kering. Produksi yang rendah menyebabkan pendapatan petani kacang tanah menjadi rendah. Oleh karena itu, kegiatan ini bertujuan untuk melakukan optimalisasi produktivitas lahan sempit melalui tumpangsari sayuran okra dengan beberapa genotipe kacang tanah.

Efektifitas penanaman tumpangsari dapat diukur dengan nilai Nisbah Kesetaraan Lahan (LER=Land Equivalent Ratio). Nilai LER merupakan perbandingan jumlah nisbah tanaman yang ditanam secara tumpangsari dengan tanaman secara tunggal pada pengelolaan yang sama (Paulus, 2005). NKL merupakan salah satu cara menghitung produktivitas lahan yang ditanam dua atau lebih jenis tanaman yang ditumpangsarikan. Sistem tumpangsari akan lebih menguntungkan bila NKL lebih besar dari satu. 
Kegiatan ini dilakukan untuk membantu mitra "Kelompok Tani Sumber Hidup" untuk meningkatkan produktivitas lahan sempit melalui tumpangsari tanaman okra-kacang tanah, seperti penggunaan varietas unggul kacang tanah, pengaturan jarak tanam, penggunaan bahan organik, pengapuran, dan-lain-lain. Kegiatan ini bertujuan untuk meningkatkan pengetahuan dan keterampilan para petani untuk meningkatkan produktivitas lahan sempit melalui pemanfaatan tumpangsari sayuran okra-kacang tanah dan mendorong para petani untuk melakukan budidaya tanaman okra dan kacang tanah secara tumpangsari.

\section{METODE}

Untuk berhasilnya pelaksanaan kegiatan penyuluhan ini, maka ada beberapa tahapan kegiatan yang telah dilaksanakan, adalah:

1. Persiapan

a. Analisis kebutuhan

Pengumpulan informasi dilakukan dengan cara observasi, wawancara dan mengikuti kegiatan yang dilakukan oleh petani. Pengumpulan data antara lain meliputi problem utama yang dihadapi, keadaan masyarakat tani baik dilihat dari segi ekonomi, pendidikan maupun pandangannya terhadap suatu inovasi baru dan lain-lain.

b. Analisis penciptaan kegiatan yang produktif

Pengumpulan data dilakukan bersamaan dengan tahap kegiatan a) meliputi masalah sumberdaya hasil pertanian (potensi, produksi, dan lain-lain) yang berhubungan dengan penciptaan kegiatan usaha yang produktif dan pemilihan paket teknologi hasil pertanian yang akan dikembangkan.

c. Sosialisasi program

Kegiatan ini bersifat pendekatan dan penyuluhan kepada masyarakat tentang manfaat dari kelanjutan program serta dampaknya terhadap tingkat pendapatan masyarakat.

d. Penentuan peserta

Peserta program yang terlibat dalam penyuluhan peningkatan produktivitas lahan sempit melalui teknologi tumpangsari sayuran okra-kacang tanah adalah 15 orang anggota dari kelompok petani.

2. Pelaksanaan program

a. Diseminasi

Pelaksanaan diseminasi dilakukan oleh tim penyuluh dengan menyampaikan informasi tentang optimalisasi produktivitas lahan sempit dengan penerapan teknologi tumpangsari sayuran okra-kacang tanah pada peserta diseminasi. Topik desiminasi akan disampaikan oleh Tim, dengan rincian topik sebagai berikut: a) kebijakan pemerintah dalam pengembangan sayuran dan kacang tanah, b) peningkatan produktivitas lahan sempit dan teknologi tumpangsari okra-kacang tanah, dan c) teknologi budidaya tanaman okra-kacang tanah (varietas dan benih unggul, bercocok tanam, pengendalian hama dan penyakit, panen dan teknologi pasca panen)

b. Demonstrasi plot

Demonstrasi dan praktek penanaman dilakukan di lahan petani. Petani secara langsung ikut terlibat secara bersama-sama dari perencanaan usaha tani sampai pemanenan. Kegiatan ini melibatkan 15 orang anggota kelompok tani dengan bimbingan tim dari LPPM Universitas Mataram. 
Pengaturan demplot mengikuti pengaturan rancangan percobaan dengan menggunakan Rancangan Acak Kelompok (RAK) dengan perlakuan kultivar kacang tanah yang ditumpangsarikan dengan okra. Adapun perlakuan yang didemplotkan adalah:

$\mathrm{O} \quad=$ Okra yang ditanam secara monokultur

$\mathrm{T} \quad=$ Kultivar Takar yang ditanam secara monokultur

$\mathrm{Bt} \quad=$ Kacang tanah Varietas Banteng yang ditanam secara monokultur

$\mathrm{Bi} \quad=$ Kultivar Bison yang ditanam secara monokultur

$\mathrm{O}+\mathrm{T}=$ Okra yang ditumpangsarikan dengan Kultivar Takar

$\mathrm{O}+\mathrm{Bt}=$ Okra yang ditumpangsarikan dengan Kultivar Banteng

$\mathrm{O}+\mathrm{Bi}=$ Okra yang ditumpangsarikan dengan Kultivar Bison

\section{HASIL DAN PEMBAHASAN}

Kegiatan pengabdian pada masyarakat telah melaksanakan dua program kegiatan yaitu kegiatan diseminasi (penyuluhan) dan demonstrasi plot.

\section{Kegiatan Penyuluhan (ceramah)}

Kegiatan penyuluhan dilakukan dengan penyampaian materi penyuluhan yang sesuai dengan topik kegiatan. Penyampaian materi penyuluhan merupakan salah satu bentuk media komunikasi untuk mengembangkan informasi pada kegiatan diseminasi hasil-hasil penelitian (Slamet, 2003). Hasil temuan dari peneliti harus dapat dimanfaatkan oleh pengguna akhir (masyarakat tani) dan pengguna antara, sehingga mekanisme dan metode yang tepat harus dilakukan. Kegiatan penyuluhan (ceramah) merupakan salah satu metode pendekatan kelompok yang digunakan untuk dapat memberikan informasi yang lebih terperinci tentang sesuatu teknologi, sehingga kegiatan penyuluhan dapat membantu seseorang dari tahap menginginkan ke tahap mencoba atau bahkan ketahap menerapkan. Agar suatu kegiatan penelitian mencapai keberhasilan dalam proses adopsinya maka suatu teknologi perlu diperdengarkan, diperlihatkan, dan dilakukan, sehingga dalam pelaksanaan pelatihan selain pemberian informasi dalam bentuk ceramah/diskusi perlu dilanjutkan dengan kegiatan praktek.

Kegiatan ini diawali dengan pengenalan peneliti dan anggota kelompok tani. Kegiatan ini dihadiri oleh anggota Kelompok Tani "Sumber Hidup". Peneliti telah menyampaikan materi ceramah yang meliputi tentang a) kebijakan pemerintah dalam pengembangan sayuran dan kacang tanah, b) peningkatan produktivitas lahan sempit dan teknologi tumpangsari okra-kacang tanah, dan c) teknologi budidaya tanaman okra-kacang tanah (varietas dan benih unggul, bercocok tanam, pengendalian hama dan penyakit, panen dan teknologi pasca panen).

Hasil kegiatan tahap ini menunjukkan bahwa para peserta sangat antosias dan terjadi diskusi dan tanya jawab antara peserta dengan Tim. Hal ini dapat dilihat dari kehadiran para peserta dan keterlibatan para peserta dalam kegiatan ini. Kehadiran peserta sesuai dengan target yaitu sejumlah 15 orang peserta.

Kegiatan ceramah telah dilaksanakan di sekitar areal tanam usaha tani petani. Kegiatan ini sengaja dipilih agar petani dapat langsung praktek dan membandingkan cara yang petani lakukan dengan teknologi yang disampaikan oleh peneliti. Kegiatan ceramah dilakukan sebelum pelaksanaan demplot, sehingga kalau ada yang ditanyakan dapat langsung dijelaskan saat demplot. Kegiatan ceramah dapat dilihat pada Gambar 1. 


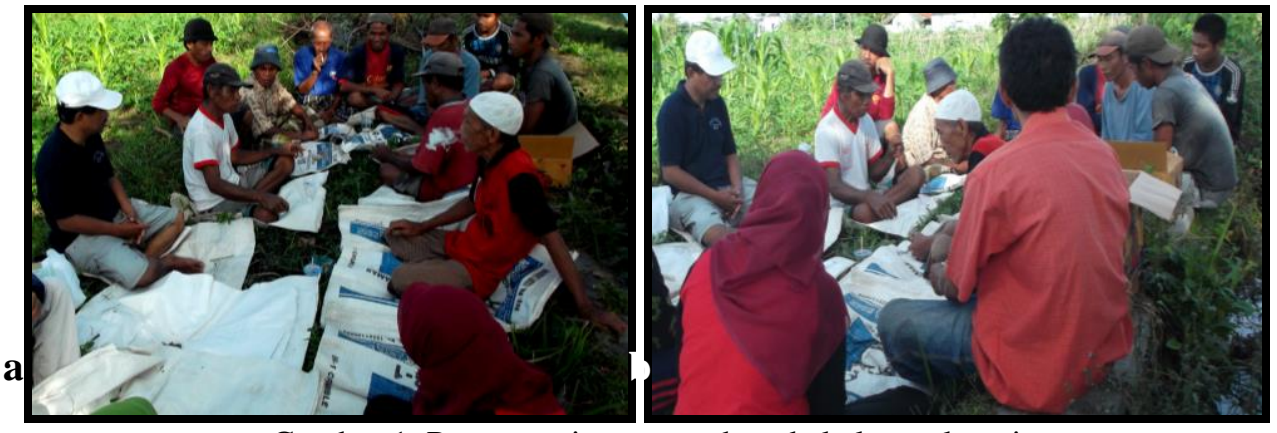

Gambar 1. Penyampaian ceramah pada kelompok tani

\section{Demonstrasi plot (Demplot)}

Demonstrasi plot ini dilakukan berkaitan dengan penggunaan pola tumpangsari kacang tanah dan jagung untuk meningkatkan produksi kacang tanah telah dilakukan di lahan kering petani. Petani secara partisipatif ikut terlibat secara bersama-sama dari perencanaan, pelaksanaan dan evaluasi hasil panen (Gambar 2).

Setelah dilaksanakan ceramah, maka dilanjutkan dengan penjelasan tentang Demplot. Penjelasan demplot meliputi tentang pengolahan tanah, pembuatan plot, pembibitan okra, penerapan teknologi tumpangsari, penanaman, pemeliharaan tanaman, dan pemanenan. Pengolahan tanah telah dilakukan satu kali. Setelah diolah dilakukan pembuatan plot. Penanaman disesuaikan dengan pola tumpangsari yang diterapkan. Pada demplot ini telah diterapkan pola tumpangsari kacang tanah yang ditanam di bawah tegakan okra.
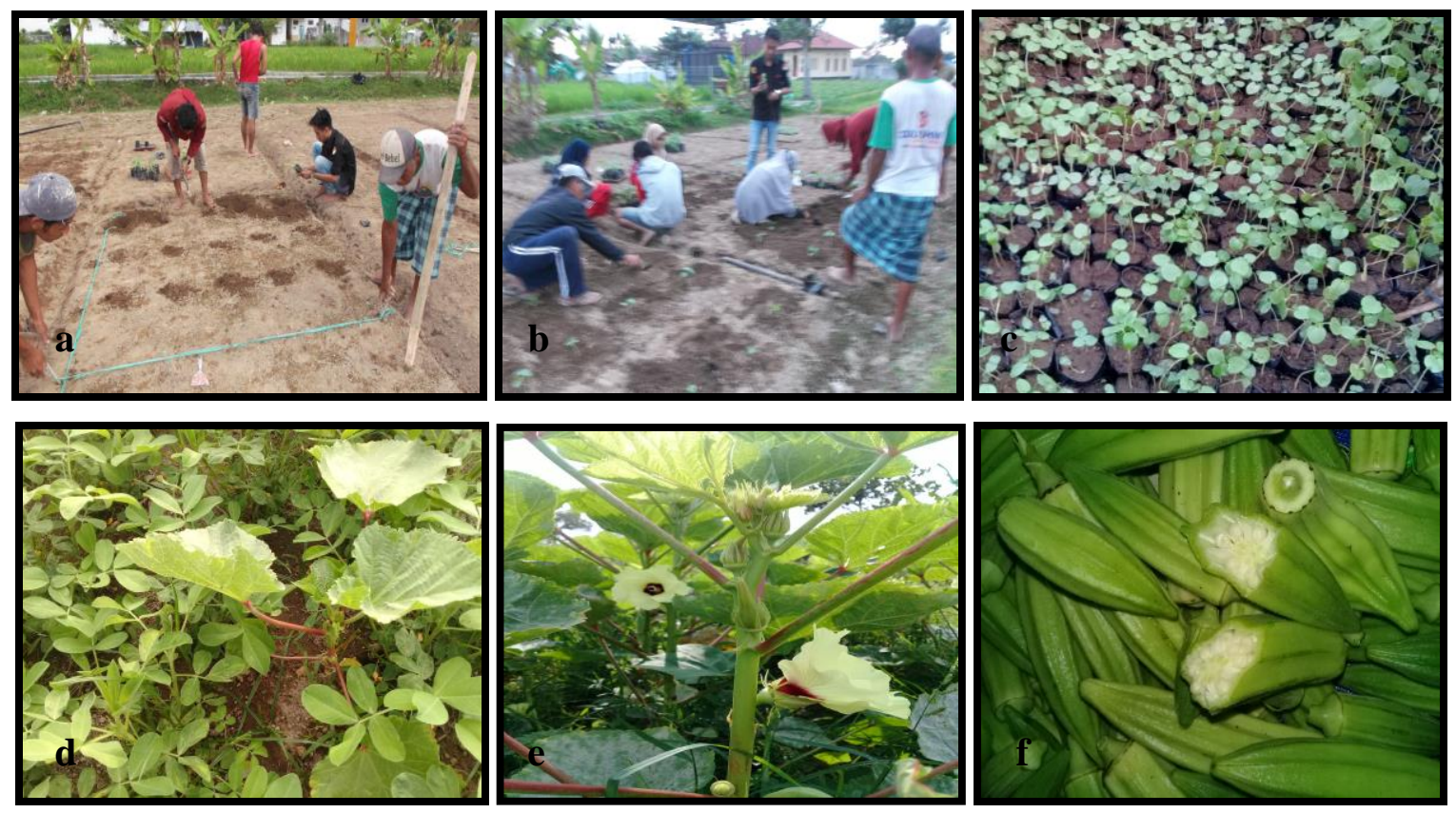

Gambar 2. Demonstrasi plot penanaman tumpangsari okra dengan kacang tanah. (a) (b) petani terlibat dalam penanaman bersama tim peneliti, (c) persiapan pembibitan okra, (d) pertumbuhan kacang tanah dan okra, (e) okra mulai berbunga dan berbuah, dan (f) hasil panen okra pada umur 60 hari setelah tanam

Penanaman okra diawali dengan persemaian. Benih okra diperoleh dari koleksi Dosen PS. Agroekoteknologi Fakultas Pertanian Universitas Mataram. Benih okra ditanam di dalam polybag berukuran 
$12 \mathrm{~cm} \times 4 \mathrm{~cm}$. Satu polybag dapat ditanam satu benih okra dengan kedalaman $1-2 \mathrm{~cm}$ dan ditutup dengan tanah secukupnya. Kemudian ditambahkan pupuk Ponska sebanyak $1 \mathrm{~g} /$ tanaman. Benih okra dibiarkan tumbuh sampai berumur 14 hari kemudian dapat dipindahkan ke lubang tanam yang sudah disiapkan.

Jarak tanam untuk penanaman okra yaitu $60 \times 40 \mathrm{~cm}$ dan jarak tanam untuk tanaman kacang tanah 40 x $20 \mathrm{~cm}$. Penanaman okra dilakukan dengan membuat lubang tanam sedalam $15 \mathrm{~cm}$ menggunakan alat tugal, tiap lubang berisi satu bibit okra kemudian bibit yang akan ditanam ditutup dengan tanah agak digundukkan. Sedangkkan penanaman untuk benih kacang tanah dilakukan dengan membuat lubang tanam sedalam $2 \mathrm{~cm}-3 \mathrm{~cm}$ menggunakan alat tugal, tiap lubang berisi 1 benih kacang tanah kemudian benih yang akan ditanam ditutup dengan tanah secukupnya.

Pemupukan pada okra dilakukan sebanyak dua kali yaitu pada saat awal tanam dengan jumlah dosis pada tanaman yaitu $10 \mathrm{~g} /$ tanaman menggunakan pupuk Ponska. Pemupukan dilakukan dengan cara ditebar secara melingkar mengelilingi tanaman okra yang ditanam secara monokultur dengan jarak pemberian pupuk dengan tanaman okra yaitu $10 \mathrm{~cm}$. Pemupukan tanaman kacang tanah yang ditanam secara monokultur dipupuk sekali pada saat awal tanam dengan dosis pada tanamnan yaitu $45 \mathrm{~g} /$ petak dengan menggunakan pupuk Ponska dan diberikan dengan cara ditebar pada tanaman kacang tanah. Untuk tanaman okra yang ditumpangsarikan dengan kacang tanah, pemupukan dilakukan sekali saja pada saat awal tanam dengan dosis $45 \mathrm{~g} /$ petak dan akan diberikan dengan cara ditebar.

Penyiangan akan dilakukan dua kali, penyiangan pertama dilakukan pada saat tanaman berumur 14 hari setelah tanam (hst) dan penyiangan kedua dilakukan pada saat tanaman berumur 25 hst sekaligus melakukan pembumbunan pada tanaman kacang tanah. Penyiangan dilakukan secara manual dan mekanis. Penyiangan secara manual akan dilakukan dengan mencabut gulma dengan tangan yang dilakukan disekitar tanaman.

Penjelasan selanjutnya adalah tentang parameter yang diamati pada penanaman kacang tanah, meliputi : untuk kacang tanah meliputi jumlah polong berisi per tanaman dan berat segar polong; untuk okra meliputi berat segar buah layak konsumsi per plot dan jumlah buah per tanaman. Petani membandingkan hasil okra monokultur, kacang tanah monokultur dan hasil okra-kacang tanah tumpangsari. Efektifitas penanaman tumpangsari dapat diukur dengan nilai Nisbah Kesetaraan Lahan (LER=Land Equivalent Ratio). LER merupakan perbandingan jumlah nisbah tanaman yang ditanam secara tumpangsari dengan tanaman secara tunggal pada pengelolaan yang sama (Paulus, 2005). Pada kegiatan tumpangsari ini petani membandingkan nilai LER monokultur dan tumpangsari. Nilai LER penanaman penanaman tumpangsari dengan monokultur disajikan pada Tabel 1. Petani membandingkan penanaman tumpangsari dengan monokultur dan ternyata nilai LER tumpangsasri 2,28 dibanding monokultur kacang tanah dan 1,35 dibanding monokultur okra. Data tersebut menunjukkan bahwa penanaman tumpangsari memberikan hasil yang lebih tinggi dibanding dengan monokultur.

Tabel 1. Nilai LER tumpangsari okra-kacang tanah di lahan sempit Desa Sigerongan

\begin{tabular}{|c|c|c|c|c|}
\hline Perlakuan & $\begin{array}{l}\text { Berat segar } \\
\text { tanah ( g/plot) }\end{array}$ & kacang & $\begin{array}{l}\text { Berat segar okra } \\
\text { (g/plot) }\end{array}$ & Nilai LER \\
\hline Okra monokultur & - & & 2.456 & \\
\hline $\begin{array}{l}\text { Kacang tanah } \\
\text { monokultur }\end{array}$ & 1.456 & & - & \\
\hline $\begin{array}{l}\text { Tumpangsari okra- } \\
\text { kacang tanah }\end{array}$ & 1.132 & & 2.184 & $\begin{array}{l}2,28 \text { dibanding monokultur kacang } \\
\text { tanah. } 1,35 \text { dibanding monokultur okra }\end{array}$ \\
\hline
\end{tabular}




\section{KESIMPULAN DAN SARAN}

\section{Kesimpulan}

Hasil kegiatan menunjukkan bahwa petani peserta penyuluhan sangat respons terhadap kegiatan diseminasi tumpangsari okra-kacang tanah. Hal ini tercermin dari antosias peserta dalam mengajukan pertanyaan dan adanya diskusi antara peserta atau penyuluh. Selain itu peserta juga aktif dalam keikutsertaan dalam setiap tahapan kegiatan seperti pemilihan benih yang baik, pembuatan demplot, penanaman, pembumbunan, penyiangan, pengendalian hama dan penyakit, dan kegiatan panen. Terjadi proses transformasi teknologi tumpangsari okra-kacang tanah di lahan sempit Desa Sigerongan Kecamatan Lingsar Kabupaten Lombok Barat, dengan harapan petani mampu memanfaatkan lahan sempit dengan menanam secara tumpangsari. Penanaman tumpangsari okra-kacang tanah lebih produktif dengan nilai LER 2,28 dibanding monokultur kacang tanah. 1,35 dibanding monokultur okra.

\section{Saran}

Peningkatan produktivitas lahan sempit di Sigerongan sebaiknya dilakukan penanaman secara tumpangsari terutama tanaman yang bernilai ekonomis tinggi dan tanaman yang bernilai gizi tinggi.

\section{Ucapan Terima Kasih}

Kegiatan pengabdian kepada masyarakat ini terlaksana atas dukungan biaya dari DIPA BLU UNRAM tahun Anggaran 2018.

\section{DAFTAR PUSTAKA}

Asadi D, Arsyad M, Zahara H, Darmijati (1997) Pemuliaan kedelai untuk toleran naungan dan tumpangsari. Buletin Agrobio. Vol. 1 (2):15-20

Franklin,AM., Suzuki, A and Nobuko Hongu, N., 2015. Okra. College of Agriculture and life science, Cooperative extention., Arizona.

Iwan, S.A. 1995. Sayuran Dataran Tinggi, Budidaya dan Pengaturan Panen. Jakarta : Penebar Swadaya.

Mihretu Y., Wayessa G., \& Adugna D., 2014. Multivariate analysis among Okra (Abelmoschus esculentus

(L.) Moench) collection in South Western Ethiopia. Journal of Plant Sciences 9(2):43-50.

Oyelade, O.J., Ade-Omowaye, B.I.O., and Adeomi, V.F., 2003. Influence of variety on protein, fat contents and some physical characteristics of okra seeds. J. Food Eng., 57: 111-114.

Paulus, J. M. 2005. Produktifitas lahan, kompetensi, dan toleransi dari tiga klon ubi jalar pada sistem tumpangsari dengan jagung. Jurusan Budidaya Pertanian,Fakultas Pertanian Universitas Lambung Mangkurat, Manado. Eugenia 11(1):1-7.

Slamet, M. 2003. Pemberdayaan Masyarakat. Dalam Membentuk Pola Perilaku Manusia Pembangunan. Penyunting: Ida Yustina dan Ajat Sudrajat, 45 - 48. IPB-Bogor 